\title{
PENURUNAN FUNGSI KOGNITIF AKIBAT DIABETES MELITUS
}

\author{
Putu Enrico Pramana Okaniawan ${ }^{1}$, Ni Nyoman Mestri Agustini ${ }^{2}$ \\ ${ }^{1}$ Prodi Kedokteran, Universitas Pendidikan Ganesha \\ ${ }^{2}$ Prodi Kedokteran, Universitas Pendidikan Ganesha \\ e-mail: enrico@undiksha.ac.id,nyoman.mestri@undiksha.ac.id
}

\begin{abstract}
Abstrak
Penyakit diabetes melitus merupakan suatu golongan penyakit sistemik yang merupakan penyakit yang dapat mempengaruhi seluruh tubuh. Berdasarkan studi neuroimaging dan neuropatologis, diabetes melitus rupanya terlibat dalam proses degenerasi saraf. Etiologi dari penurunan kemampuan kognitif ialah beberapa penyakit degeneratif seperti alzheimer. Faktor resiko dari penurunan kemampuan kognitif akibat diabetes ialah kejadian berulang episode hipoglikemia, pasien dengan manifestasi mikrovaskular (seperti diabetic retinopathy) atau penyakit makrovaskular (seperti infark atau stroke miokard), resistensi insulin, peradangan, dan depresi. Penyakit ini dapat mempengaruhi kognitif melalui gangguan pada pembuluh darah otak. Efek DMT1 terhadap gangguan kognitif dapat terjadi pada anak serta efek DMT2 dapat meningkatkan resiko gangguan kognitif ringan menjadi demensia. Saat ini belum ada teknik diagnosis dan tatalaksana yang terbaik, namun sejumlah penelitian klinis telah menyoroti potensi Traditional Chinese Medicine dalam proses tatalaksana ini
\end{abstract}

Kata kunci: Diabetes Melitus, Kognitif, Memori

\begin{abstract}
Diabetes mellitus is a group of systemic diseases which are diseases that can affect the whole body. Based on neuroimaging and neuropathological studies, diabetes mellitus is apparently involved in the process of nerve degeneration. The etiology of cognitive impairment are several degenerative diseases such as Alzheimer's. Risk factors for decreased cognitive abilities due to diabetes are recurrent episodes of hypoglycemia, patients with microvascular manifestations (such as diabetic retinopathy) or macrovascular diseases (such as myocardial infarction or stroke), insulin resistance, inflammation, and depression. This disease can affect cognitive through disorders of the brain blood vessels. The effect of DMT1 on cognitive impairment can occur in children and the effect of DMT2 can increase the risk of mild cognitive impairment into dementia. At present there are no best diagnostic and management techniques, but a number of clinical studies have highlighted the potential of Traditional Chinese Medicine in this management process.
\end{abstract}

Keywords : Diabetes Mellitus, Cognitive, Memory

GMJ | 28 


\section{PENDAHULUAN}

Penyakit diabetes melitus merupakan momok tersendiri dalam permasalahan kesehatan di masyarakat, bahkan berdasarkan data, penyakit ini menjadi salah satu penyebab utama penyakit ginjal dan kebutaan pada usia di bawah 65 tahun, dan juga amputasi selain disebabkan oleh penyakit karena sistem kardiovaskular. Berdasarkan hasil diagnosis kepada penduduk umur $\geq 15$ tahun, diagnosis menunjukan peningkatan dari tahun 2013 ke tahun 2018 menjadi 2\% (Kemenkes, 2018). Diabetes melitus (DM) adalah gangguan metabolisme kronis yang ditandai dengan hiperglikemia persisten (Goyal dan Jialal, 2020). Seseorang dapat dikatakan diabetes jika mengalami hiperglikemia dengan glukosa darah puasa lebih besar dari $125 \mathrm{mg} / \mathrm{dL}$ (Mouri dan Badireddy, 2020).

Diabetes melitus dapat dibedakan menjadi diabetes melitus tipe 1 (DMT1) dan diabetes melitus tipe 2 (DMT2). DMT1 menyumbang $5 \%$ hingga $10 \%$ dari DM dan ditandai dengan suatu sistem autoimun yang menyebabkan penghancuran sel beta penghasil insulin pada pankreas. DMT1 paling sering terlihat pada anakanak dan remaja meskipun dapat berkembang pada usia berapa pun. DMT2 menyumbang sekitar $90 \%$ dari semua kasus diabetes. Pada DMT2, terjadi pengurangan respons terhadap insulin atau biasa disebut resistensi insulin. DMT2 paling sering diderita oleh usia di atas 45 tahun (Goyal dan Jialal, 2020). Diabetes melitus pula dapat digolongkan sebagai suatu jenis penyakit sistemik. Penyakit sistemik merupakan penyakit yang dapat mempengaruhi seluruh tubuh dan bukan hanya satu organ atau bagian tubuh tertentu (infeksi lokal) (Vorvick, 2019).

Peran diabetes dalam degenerasi saraf telah dikonfirmasi oleh studi neuroimaging dan neuropatologis. Studi MRI telah menunjukkan bahwa diabetes melitus tipe 2 (DMT2) sangat terkait dengan atrofi otak. Tingkat atrofi otak global pada DMT2 hingga 3 kali lebih cepat dari pada penuaan normal. Diabetes juga dikaitkan dengan peningkatan peluang penurunan kognitif sebagaimana ditentukan oleh skor MMSE (Mini-Mental State Examination) (Saedi et al., 2016). Paparan kronis hiperglikemia dapat memperburuk fungsi kognitif karena selain dapat menyebabkan skizofrenia, penyakit ini pula dapat menyebabkan terjadinya penyakit penurunan fungsi kognitif lainnya seperti alzheimer dan demensia, (Lee et al, 2018).

Data saat ini menunjukkan bahwa kedua jenis diabetes melitus memiliki hubungannya yang kuat dengan penurunan fungsi kognitif (Moheet et al, 2015). Kemampuan fungsi kognitif adalah kemampuan dalam melakukan atensi, registrasi, memori, kalkulasi, recall, bahasa, pertimbangan, menulis, membaca serta kemampuan dalam visuospasial (Tsalissavrina et al., 2018).

DMT2 meningkatkan resiko jangka panjang demensia hampir 2 kali lipat (Biessels et al., 2014). Demensia sangat lazim pada orang tua, dan 
merupakan bagian penting dari kecacatan terkait usia. Dengan proporsi orang berusia 65 tahun yang diperkirakan akan meningkat hingga di atas $20 \%$ pada tahun 2050 , kejadian demensia diperkirakan akan meningkat secara dramatis. Otak yang menua menimbulkan perubahan patologis yang disebabkan oleh berbagai faktor resiko, dan ini dapat mengubah ambang klinis untuk demensia pada seseorang (Verdile et al., 2015).

Oleh karena penurunan fungsi kognitif akibat diabetes melitus merupakan kasus yang cenderung umum diderita oleh segala jenis umur di Indonesia dan dunia, penting kiranya untuk dilakukan studi referensi terkait dengan etiologi, faktor resiko, patofisiologi, efek spesifik antara DMT1 dan DMT2 terhadap penurunan fungsi kognitif, tata cara diagnosis, dan tatalaksana dari kasus tersebut.

\section{HASIL DAN PEMBAHASAN}

Etiologi dari gangguan yang dapat menyebabkan hilangnya memori dan juga dapat menyebabkan gangguan kognitif ialah alzheimer, demensia vaskular, depresi dan kecemasan, efek samping obat, gangguan tidur, hormon, gangguan metabolisme, diabetes, penyalahgunaan alkohol, penyakit lyme, sklerosis hippocampal, hematoma subdual dan epidural, kekurangan vitamin B12, kekurangan vitamin, kejang, HIV terkait gangguan neurokognitif, dan ensefalopati hashimoto (Saedi et al, 2016).

Beberapa ahli telah menemukan faktor resiko dari penurunan fungsi kognitif oleh akibat DM. Faktor resiko tersebut ialah kejadian berulang episode hipoglikemia yang dapat menyebabkan penurunan kognitif dan peningkatan resiko demensia. Lalu, pasien dengan manifestasi mikrovaskular (seperti diabetic retinopathy) atau penyakit makrovaskular (seperti infark atau stroke miokard) memiliki kinerja kognitif yang lebih buruk dan berada pada peningkatan resiko demensia dibandingkan dengan orang yang tidak memiliki manifestasi ini. Selain itu, resistensi insulin, peradangan, dan depresi pula menjadi suatu faktor resiko potensial untuk disfungsi kognitif pada orang dengan diabetes (Biessels dan Despa, 2018).

Hipertensi pula telah terbukti menjadi faktor resiko yang signifikan untuk kinerja kognitif yang buruk pada pasien DMT1 dan DMT2. Selain hipertensi, dislipidemia aterogenik adalah faktor resiko vaskular lain yang umum pada DM (Seto et al, 2015).

Salah satu bukti konvergen menunjukkan bahwa peningkatan kadar HbA1C rupanya dapat menyebabkan penurunan kognitif oleh karena DM. Namun pendapat tersebut masih mendapat sanggahan oleh karena terdapat korelasi yang cenderung masih lemah karena peningkatan kadar HbA1C atau pengukuran glukosa berulang selama bertahun-tahun pada pasien nondiabetes pula dapat dikaitkan dengan peningkatan resiko demensia pada orang tanpa diabetes. Hanya beberapa penelitian yang meneliti hubungan antara kadar $\mathrm{HbA1C}$ dan resiko demensia pada diabetis, dan hasil penelitian ini telah menunjukkan indikasi non-linier, di mana kadar $\mathrm{HbA1C}$ yang rendah maupun tinggi

GMJ | 30 
tetap terkait dengan peningkatan resiko demensia (Biessels dan Despa, 2018).

Ketidaknormalan dalam pensinyalan insulin dan sensitivitas reseptor insulin dalam neuron dan proses dendritik pada penyakit alzheimer telah menyebabkan hipotesis bahwa disfungsi metabolik mungkin terkait dengan disfungsi reseptor insulin. Sumber insulin dalam otak tidak pasti dan mungkin berasal dari insulin yang melintasi penghalang darah otak melalui saturable transporter. Secara umum pensinyalan insulin meningkatkan memori dan memfasilitasi plastisitas sinaptik dalam hippocampus yang memiliki peran penting dalam memori dan pembelajaran. Dalam otak mamalia yang sehat, insulin memfasilitasi potensiasi Long-Term Hippocampal (LTH), kemampuan dalam pembelajaran, memori, serta meningkatkan ekspresi reseptor aspartat N-metil-D-aspartat. Insulin juga mengatur konsentrasi beberapa neurotransmiter yang memiliki peran dalam pembentukan memori, seperti asetilkolin, norepinefrin dan epinefrin, dan mempromosikan akumulasi reseptor $\mathrm{GABA}(\mathrm{A})$ ke membran pascasinaptik (Zilliox et al, 2016).

Diabetes melitus dapat menyebabkan resiko gangguan kognitif melalui gangguan pada pembuluh darah termasuk diantaranya pembuluh darah di otak. Kondisi glukosa darah yang tidak terkontrol dapat menyebabkan efek toksik di otak. Adanya stress oksidatif dan akumulasi advanced glycation end products (AGEs) berpotensi pada kerusakan jaringan otak di hipokampus. Selain itu terdapat beberapa faktor lain yang mempengaruhi hubungan antara DM dengan penurunan fungsi kognitif, yaitu melalui plak pada aterosklerosis, penyakit mikrovaskuler, ataupun faktor sekunder seperti faktor usia atau penuaan, faktor genetic maupun penyakit penyerta, serta lama menderita DM dan kadar glukosa darah juga dapat mempengaruhi fungsi kognitif penderita DM (Tsalissavrina et al, 2018).

Disfungsi mitokondria adalah salah satu faktor yang dapat menyebabkan penyakit alzheimer oleh karena obesitas dan diabetes. Sebagai contoh, kerusakan rantai pernapasan telah diamati pada mitokondria yang diisolasi dari tikus transgenik alzheimer sukrosa yang diberi makan (Pugazhenthi dan Reddy, 2017).

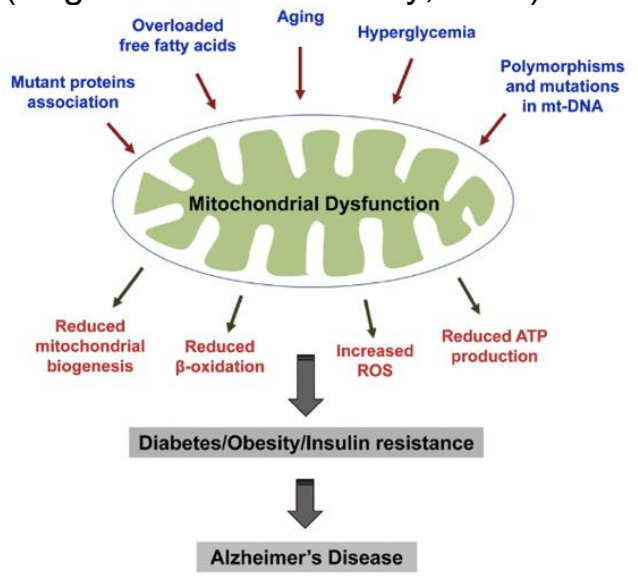

Gambar 1 Disfungsi Mitokondria (Pugazhenthi dan Reddy, 2017)

Gambar 1 menjelaskan bahwa beberapa faktor yang diketahui menyebabkan disfungsi mitokondria. Faktor-faktor ini termasuk penuaan, peningkatan asam lemak bebas, hiperglikemia, polimorfisme dan mutasi 
DNA dalam genom mitokondria dan hubungan protein mutan dengan mitokondria. Mitokondria disfungsional menghasilkan ATP berkurang, penurunan biogenesis, gangguan oksidasi beta dan peningkatan Reactive Oxygen Species (ROS). Peristiwa ini dapat berkontribusi pada diabetes, obesitas, dan resistensi insulin yang pada akhirnya menyebabkan penyakit alzheimer pada orang lanjut usia (Pugazhenthi dan Reddy, 2017).

Selain faktor disfungsi mitokondria, terdapat pula peningkatan ekspresi sitokin proinflamasi di otak dalam kondisi diabetes dan ini memainkan peran penting dalam kerusakan neuron (Gaspar et al, 2016). NF-kB telah dipostulatkan untuk terlibat dalam fungsi kognitif. BAY 11-7082 (BAY) adalah inhibitor farmakologis dari IkBa (inhibitor kappa B alpha) fosforilasi yang menghambat aktivasi NF-kB dan menurunkan kadar interleukin-6 (IL-6) dan tumor necrosis factor (TNF). Pada tikus DMT2, BAY meningkatkan pembelajaran dan kinerja memori tanpa mempengaruhi kontrol glikemik (Datusalia dan Sharma, 2016). Pada hippocampus oleh manusia dengan postmortem diabetik, terdapat aktivasi mikroglia yang serupa dengan yang diamati pada pasien alzheimer. Tikus yang diberi diet tinggi lemak telah meningkatkan kadar TNF dan aktivasi mikroglia/makrofag di otak yang konsisten dengan perubahan proinflamasi di otak. ROS pada otak diabetes mengaktifkan beberapa jalur seluler termasuk advanced glycation end products, jalur poliol, dan protein kinase $C$ (PKC), yang mengarah pada peningkatan peradangan otak dan neurodegenerasi. NF-kB juga merupakan modulator ROS dan mengatur ekspresi TNF dan interleukin, serta memainkan peran utama dalam inisiasi kaskade inflamasi. Upregulasi TNF juga menghambat pensinyalan insulin yang mengarah pada peningkatan generasi ROS dan gangguan kognitif (Zilliox et al, 2016).

Dislipidemia pula berkontribusi terhadap perkembangan aterosklerosis dan telah ditemukan dapat meningkatkan resiko demensia pada diabetes. Selain itu, berkurangnya aliran darah otak, peningkatan regulasi sitokin inflamasi, disfungsi endotel, dan kelainan pada kapiler otak telah ditunjukkan pada pasien dengan diabetes. Perubahan pembuluh darah otak oleh faktor-faktor ini terkait erat dengan stroke dan kerusakan otak, termasuk infark otak dan lesi white matter, serta berkontribusi terhadap penurunan kognisi pada diabetes (Seto et al, 2015).

Terdapat temuan bahwa hubungan DMT1 dan gangguan kognitif terjadi pada anak-anak (Cato et al, 2014). Fleksibilitas kognitif, persepsi visual, kecepatan psikomotorik, dan perhatian adalah domain utama yang sebagian besar dipengaruhi dalam waktu 2 tahun pada DMT1, yang salah satu di antaranya ialah perlambatan mental. Fungsi belajar dan memori tampaknya masih utuh bahkan dalam hiperglikemia yang berkepanjangan di DMT1. Usia muda merupakan faktor resiko penting dalam mengembangkan defisit kognitif pada DMT1. Tampaknya anak-anak yang memiliki penyakit yang terdiagnosis di bawah usia 7 tahun berada pada resiko yang lebih besar untuk disfungsi kognitif yang lebih parah. Tomografi emisi foton tunggal

GMJ | 32 
pada pasien diabetes menunjukkan kelainan di banyak daerah otak, yang berkorelasi terutama dengan komplikasi mikrovaskuler diabetik dan kontrol glikemik yang buruk pada DMT1. Namun, tidak ada bukti kuat untuk mendukung pentingnya kelainan perfusi otak dalam perkembangan disfungsi kognitif pada DMT1 (Saedi et al, 2016).

Ada beberapa hubungan erat antara diabetes dan demensia vaskular yang berada di atas $100 \%$ hingga $160 \%$ jika dibandingkan dengan penyakit alzheimer yaitu hanya sekitar 45\% hingga 90\% (Saedi et al, 2016). DMT2 dapat meningkatkan resiko pengembangan gangguan kognitif ringan menjadi demensia (Biessels et al, 2014). Bahkan dalam kondisi pradiabetes; ada peningkatan resiko penyakit alzheimer dan demensia yang tidak terkait dengan perkembangan diabetes di masa depan. Sekitar $80 \%$ dari penderita penyakit alzheimer mungkin menderita diabetes atau gangguan glukosa puasa. Ada penurunan yang lebih cepat dari kognisi pada pasien diabetes daripada orang tua non-diabetes. Diabetes dikaitkan dengan 1,5-2 kali peningkatan resiko kecelakaan serebrovaskular dan resiko relatif stroke meningkat 1,15 (95\% Cardiac Infark: 1,08-1,23) untuk setiap peningkatan $1 \%$ dalam HbA1C (Saedi et al, 2016)

Tes neuropsikologis terbaik untuk mengevaluasi gangguan kognitif pada diabetes rupanya belum ditetapkan. Pemeriksaan keadaan mental dan Montreal Cognitive Assessment (MOCA) adalah dua tes skrining yang sering dilakukan dalam klinis. Pengujian yang lebih mendalam dan sensitif melibatkan evaluasi mendalam dari berbagai domain kognitif. Tes dapat mengevaluasi lebih dari satu domain. Lima domain kognitif yang dinilai secara umum meliputi: penalaran abstrak; memori, dengan subdomain dari memori yang berfungsi, memori langsung dan tingkat belajar, laju lupa, dan memori incidental, kecepatan pemrosesan informasi, perhatian dan fungsi eksekutif, serta keterampilan visuospatial. Penalaran abstrak seperti tes penyortiran Kartu Wisconsin adalah kemampuan untuk mengonseptualisasikan dan menganalisis informasi serta mengenali hubungan dan pola untuk memecahkan masalah pada tingkat yang tidak berwujud. Memori yang bekerja misalnya rentang digit maju dan mundur memungkinkan seseorang untuk menyimpan dan memproses informasi. Memori langsung sering disebut sebagai memori jangka pendek dan mewakili kemampuan untuk mengingat informasi untuk waktu yang singkat, tetapi tidak untuk memanipulasi informasi tersebut. Memori langsung dapat dinilai oleh Tes Pembelajaran untuk memori verbal ialah Verbal Auditori Rey dan tes untuk memori visual adalah Location Learning Test. Tes untuk memori insidental misalnya Taylor Complex Figure Test adalah tes untuk mengetahui memori terkait informasi yang orang tidak diminta untuk mengingatnya. Kecepatan pemrosesan informasi menentukan efisiensi fungsi kognitif. Itu dinilai oleh tugas waktunya seperti tes pembuatan jejak dan tes warna kata stroop. Fungsi eksekutif (misalnya, pembuatan jejak, warna-warna stroop, kelancaran huruf, dan tes kelancaran kategori) diperlukan untuk menganalisis

GMJ | 33 
suatu situasi, mengembangkan, dan melaksanakan rencana. Visuoconstruction mengacu pada kemampuan untuk melihat objek atau gambar sebagai seperangkat bagian dan kemampuan untuk membangun replika yang asli dari bagian-bagian tersebut. Keterampilan visuospatial misalnya Rey-Osterrieth Complex Figure Test diperlukan untuk persepsi kedalaman, mengenali lingkungan dan wajah, menemukan objek dan membaca (Zilliox et al, 2016)

Pasien dengan DMT2 telah ditemukan memiliki kecepatan mental yang lebih lambat dan mengurangi fleksibilitas mental dibandingkan dengan kontrol non-diabetes. Sebuah meta-analisis dari 24 studi yang mencakup total lebih dari 26.000 pasien dimana terdapat 3351 dengan diabetes dan 22.786 kontrol non-diabetes, menemukan bahwa individu dengan DMT2 ternyata lebih buruk pada tes neurokognitif dibandingkan dengan kontrol non-diabetes. Pasien dengan DMT2 menunjukkan penurunan terbesar dalam fungsi motorik, fungsi eksekutif, kecepatan pemrosesan, memori verbal, dan memori visual (Palta et al, 2014)

Selain pemeriksaan keadaan mental, pencitraan otak dapat menjadi alat penting untuk mengklarifikasi patogenesis yang mendasari gangguan kognitif pada pasien diabetes. Beberapa peneliti telah melaporkan perubahan otak global dan fokal. Kelainan struktural otak yang ringan telah dilaporkan pada DMT1. Sebuah studi menunjukkan bahwa kepadatan materi abu-abu pasien dengan DMT1 kurang dari kelompok kontrol dan temuan ini berkorelasi dengan serangan hipoglikemik yang parah dan kadar HbA1c yang lebih tinggi. Penilaian ini dilakukan dengan morfometri berbasis voxel - quantitative MRI technique yang terkenal (Saedi et al., 2016).

Menurut penelitian, ada beberapa rekomendasi pengobatan dalam mengatasi penurunan kognisi akibat diabetes melitus. Namun obat-obatan yang direkomendasikan belum ada yang merupakan obat pasti dan masih dalam proses uji coba.

Obat yang pertama adalah obat anti-diabetes yaitu kelas thiazolidinedione yang baru sampai uji tahap percobaan pada tikus yang merupakan sensitizer insulin yang bekerja dengan membuat sel-sel lebih sensitif terhadap insulin. Efek dari obat ini mampu mengurangi apoptosis pada neuron, melindungi neuron dari stres oksidatif, dan mengurangi pembentukan plak dan peradangan. Namun, uji klinis saat diterapkan pada manusia masih mengecewakan (Saedi et al., 2016).

Lalu menurut penelitian prospektif jangka panjang, kontrol diabetes yang baik bermanfaat dalam pengurangan penurunan kognitif pada DMT1, tetapi efek dari pendekatan ini pada DMT2 masih kontroversial. Dalam satu studi kohort, ada penurunan yang lebih besar dalam penurunan kognitif pada pasien yang menggunakan obat anti-diabetes dan lebih disarankan melakukan terapi kombinasi karena masih lebih efektif daripada melakukan monoterapi (Saedi et al., 2016).

Sampai saat ini, ada beberapa data klinis tentang kemanjuran metformin pada penyakit alzheimer dan karena hasil yang bertentangan

GMJ | 34 
mengenai efek metformin dalam perbaikan atau penurunan fungsi kognitif, sehingga perlu dilakukan klarifikasi lanjutan dengan uji klinis terkontrol placebo (Saedi et al., 2016).

Dalam studi The Memory in Diabetes (ACCORD-MIND), terlihat dengan MRI bahwa pada pasien dengan DMT2 yang menerima kontrol glikemik intensif terdapat penurunan laju atrofi otak dibandingkan dengan mereka yang menerima terapi standar, namun tidak disertai dengan peningkatan fungsi kognitif. Ditemukan pula bahwa terapi insulin dengan rute intranasal mungkin lebih menjanjikan untuk meningkatkan kognisi pada DMT1 karena insulin dapat mengurangi plak amiloid intraseluler, meningkatkan hipofosforilasi, yang menstabilkan mikrotubulus, dan mendorong polimerisasi tubulin (Zilliox et al, 2016).

Upaya besar telah diinvestasikan untuk memahami efek diabetes pada penurunan kognitif dan demensia dalam dekade terakhir. Studi terbaru telah mengidentifikasi faktor-faktor resiko dan mekanisme yang mungkin mendasari patogenesis disfungsi kognitif yang dimediasi-DM. Dengan mengambil keuntungan dari kemajuan terbaru dalam proses ini, dimungkinkan untuk mengembangkan terapi yang lebih baik untuk komplikasi kognitif terkait DM, termasuk penyakit alzheimer, demensia vaskular, dan penurunan kognitif. Sejumlah penelitian klinis telah menyoroti potensi Traditional Chinese Medicine (TCM) dalam pengobatan penurunan kognitif terkait DM. Terlepas dari kenyataan bahwa sebagian besar percobaan ini telah menunjukkan hasil positif, masalah metodologis yang signifikan seperti ukuran sampel kecil dan pengacakan yang buruk ada di banyak penelitian ini. Oleh karena itu, diperlukan uji coba terkontrol acak yang lebih ketat yang bertujuan untuk lebih memvalidasi temuan ini. Akhirnya, sebagian besar studi praklinis menilai efek Chinese Herbal Medicines (CHM) pada disfungsi kognitif yang dimediasi DM yang dilakukan dengan menggunakan ramuan tunggal atau bahan aktif terisolasi. Mengingat bahwa penggunaan $\mathrm{CHM}$ didasarkan pada formulasi kompleks, penelitian lebih lanjut tentang efek sinergis kombinasi herbal diperlukan untuk pemahaman yang lebih komprehensif tentang mekanisme yang mendasari efeknya pada penyakit (Seto et al, 2015).

\section{SIMPULAN}

Diabetes melitus merupakan penyakit sistemik yang dapat menyerang lebih dari satu organ tubuh yang merupakan momok tersendiri karena kemampuannya dalam merusak tubuh mendapat peringkat yang hampir setara dengan penyakit kardiovaskular. Penyakit ini berperan dalam penurunan fungsi kognitif pada pasien usia lanjut. Etiologi dari penurunan kemampuan kognitif dan memori ialah beberapa penyakit degeneratif seperti Alzheimer. Faktor resiko dari penurunan kemampuan kognitif akibat diabetes ialah kejadian berulang episode hipoglikemia, pasien dengan manifestasi mikrovaskular (seperti diabetic retinopathy) atau penyakit makrovaskular (seperti infark atau stroke miokard), resistensi insulin, peradangan, dan depresi.

Penyakit ini dapat mempengarhui kognitif melalui gangguan pada 
pembuluh darah termasuk diantaranya pembuluh darah di otak. Kondisi glukosa darah yang tidak terkontrol dapat menyebabkan efek toksik di otak. Adanya stress oksidatif dan akumulasi advanced glycation and products (AGEs) berpotensi pada kerusakan jaringan otak di hipokampus. Disfungsi mitokondria adalah salah satu faktor yang dapat menyebabkan Alzheimer oleh karena obesitas dan diabetes. Sebagai contoh, kerusakan rantai pernapasan telah diamati pada mitokondria yang diisolasi dari tikus transgenic Alzheimer sukrosa yang diberi makan. Selain faktor disfungsi mitokondria, terdapat pula peningkatan ekspresi sitokin proinflamasi di otak dalam kondisi diabetes dan ini memainkan peran penting dalam kerusakan neuron.

Terdapat efek spesifik antara DMT 1 dan DMT2 terhadap penurunan fungsi kognitif dimana terdapat temuan bahwa hubungan DMT1 dan gangguan kognitif terjadi pada anak-anak dan fleksibilitas kognitif, persepsi visual, kecepatan psikomotorik, dan perhatian adalah domain utama yang sebagian besar dipengaruhi. DMT2 juga meningkatkan resiko pengembangan gangguan kognitif ringan menjadi demensia.

Dalam hal mendiagnosis dari penyakit ini rupanya belum ditetapkannya tes neuropsikologis terbaik untuk mengevaluasi gangguan kognitif pada diabetes. Alternatif yang digunakan untuk mendiagnosis adalah penilaian keadaan mental dan pencitraan.

Sama halnya dengan teknik diagnosis, menurut penelitian belum ada obat pasti yang direkomendasikan dalam pengobatan kelainan ini karena masih dalam tahap uji coba, namun sejumlah penelitian klinis telah menyoroti potensi traditional Chinese medicine (TCM) dalam pengobatan penurunan kognitif terkait DM.

\section{DAFTAR RUJUKAN}

Biessels, G. J., \& Despa, F. (2018). Cognitive decline and dementia in diabetes mellitus: mechanisms and clinical implications. Nature Reviews Endocrinology.

Biessels, G.J., Strachan, M.W., Visseren, F.L., Kappelle, L.J., Whitmer, R.A. (2014). Dementia and cognitive decline in type 2 diabetes and prediabetic stages: towards targeted interventions. Lancet Diabetes Endocrinol. 2, 246-255.

Cato, M.A., Mauras, N., Ambrosino, J., Bondurant, A., Conrad, A.L., Kollman, C., Cheng, P., Beck, R.W., Ruedy, K.J., Aye, T., et al. (2014). Cognitive functioning in young children with type 1 diabetes. J Int Neuropsychol Soc,20,238-247.

Datusalia, A.K., Sharma, S.S., (2016). NF-kappaB inhibition resolves cognitive deficits in experimental type 2 diabetes mellitus through CREB and Glutamate/GABAneurotransmitt ers pathway. Curr Neurovasc Res.,13(1),22-32.

Gaspar, J.M., Baptista, F.I., Macedo, M.P., Ambrosio, A.F., (2016). Inside the diabetic brain: role of different players involved in cognitive decline. ACS Chem Neurosci,7(2),131-42. 
Goyal, R. dan Jialal I. (2020). Diabetes Mellitus Type 2. In: StatPearls. Treasure Island (FL): StatPearls Publishing. Pp 1-12. Diakses pada:

https://www.ncbi.nlm.nih.gov/bo oks/NBK513253/?report=classic

Kementrian Kesehatan. (2018). Hasil Utama Riset Kesehatan Dasar. Jakarta: Kementrian Kesehatan.

Lee, H. J., Seo, H. I., Cha, H. Y., Yang, Y. J., Kwon, S. H., \& Yang, S. J. (2018). Diabetes and Alzheimer's Disease: Mechanisms and Nutritional Aspects. Clinical nutrition research, 7(4), 229-240.

Moheet, A., Mangia, S., \& Seaquist, E. R. (2015). Impact of diabetes on cognitive function and brain structure. Annals of the New York Academy of Sciences, 1353(1), 60-71.

Palta, P., Schneider, A.L., Biessels, G.J., Touradji, P., Hill-Briggs, F. (2014). Magnitude of cognitive dysfunction in adults with type 2 diabetes: a meta-analysis of six cognitive domains and the most frequently reported neuropsychological tests within domains. J Int Neuropsychol Soc.,20(3),278-91.

Pugazhenthi, S.Q.L. dan Reddy, P.H. (2017). Common neurodegenerative pathways in obesity, diabetes, and Alzheimer's disease. Biochimica et Biophysica Acta (BBA) Molecular Basis of Disease, 1863(5), 1037-1045.

Saedi, E. et al. (2016). 'Diabetes mellitus and cognitive impairments', 7(17), 412-422.
Seto, S. W., Yang, G. Y., Kiat, H., Bensoussan, A., Kwan, Y. W., \& Chang, D. (2015). Diabetes Mellitus, Cognitive Impairment, and Traditional Chinese Medicine. International Journal of Endocrinology, 2015, 1-14.

Tsalissavrina, I. et al. (2018) 'Hubungan Lama Terdiagnosa Diabetes dan Kadar Glukosa Darah Dengan Fungsi Kognitif Penderita Diabetes Tipe $2 \mathrm{Di}$ Jawa Timur, 3(1), 28-33.

Vorvick, L. J. (2019) Systemic. Diakses pada:

https://medlineplus.gov/ency/arti cle/002294. htm.

Zilliox, L. A., Chadrasekaran, K., Kwan, J. Y., \& Russell, J. W. (2016). Diabetes and Cognitive Impairment. Current diabetes reports, 16(9), 87. 